\title{
Aspectos funcionais e imunológico do transplante autólogo da tireóide em ratos ${ }^{1}$
}

\author{
Functional and immunologic aspects of thyroid autologous transplantation in rats
}

\author{
José Carlos Nunes Mota ${ }^{2}$, Alcino Lázaro da Silva ${ }^{3}$, Aryon de Almeida Barbosa Júnior ${ }^{4}$, Murilo Nascimento ${ }^{5}$ \\ 1. Trabalho realizado no Curso de Pós-Graduação em Cirurgia da Faculdade de Medicina da Universidade Federal de Minas Gerais (FM- \\ UFMG) e Centro de Pesquisa Gonçalo Moniz (FIOCRUZ/BA). \\ 2. Mestre e Doutor em Cirurgia FM-UFMG; Cirurgião Geral. \\ 3. Professor Titular de Cirurgia do Aparelho Digestivo FM-UFMG. \\ 4. Patologista, Mestre, Doutor em Medicina; Pesquisador Titular da Fundação Oswaldo Cruz/Centro de Pesquisa Gonçalo Moniz \\ (FIOCRUZ/BA). \\ 5. Chefe do Laboratório Pedro Teixeira, Salvador-BA.
}

\section{RESUMO}

Objetivo: Investigar a produção dos hormônios da tireóide transplantada no mesentério. Métodos: Foram operados quarenta e dois ratos Wistar, distribuídos em três grupos. No grupo 1, 30 ratos dos quais colheu-se o sangue para dosagem dos hormônios. O lobo esquerdo da tireóide do rato foi dividido em dois fragmentos e transplantados para o mesentério. O implante foi removido do mesentério e encaminhado para análise histológica e morfométrica. O grupo 2, com 10 ratos, para testar a sobrevivência dos animais somente com os implantes por cem dias, isto é sem a tireóide in situ. Grupo 3, com 2 animais para o estudo do enxerto à microscopia eletrônica. Resultados: A histologia, a morfometria e a microscopia eletrônica revelram o tecido enxertado nos limites da normalidade, bem como os hormônios $\mathrm{T}_{3}$ e $\mathrm{T}_{4}$. O TSH esteve bastante alto, mas no fim do período de 75 dias, houve um declínio em direção ao valor referencial, porém se manteve aumentado. A imunogamaglobulina não sofreu alteração. Conclusão: Os hormônios $\mathrm{T}_{3}$ e $\mathrm{T}_{4}$ refletem a regularidade do tecido tireóideo transplantado na raiz do mesentério. O TSH se mantém aumentado e a imunogamaglobulina sem alteração estatisticamente significante. É possível fazer com segurança o transplante experimental autólogo da tireóide.

Descritores: Transplante Autólogo. Glândula Tireóide. Tireoidectomia.

\begin{abstract}
Purpose: To study the hormonal production of the thyroid transplanted into the mesenteric fatty tissue. Methods: Forty-two Wistar rats were used, 30 in the experimental group and 12 as controls, to test survival after 100 days of transplantation. Half of the thyroid was removed and implanted into the mesenteric tissue. Ten days later the half of the gland left in situ was removed. Levels of thyroid hormones were measured at several different periods after transplantation, in serum from peripheral blood. Removed tissue was submitted to histological, morphometric and ultrastructural analysis. Results: Morphologic studies were within normal limits. . The $\mathrm{T}_{3}$ and $\mathrm{T}_{4}$ hormones maintained their normal levels. TSH levels showed marked elevation, which subsided around the 75 day of transplantation, but remained elevated during the entire experimental period. Levels of gammaglobulin remained within normal limits. Conclusion: Levels of $\mathrm{T}_{3}$ and $\mathrm{T}_{4}$ reflected the preservation of good thyroid function during mesenteric transplantation. The increased TSH levels revealed pituitary stimulation to a reduced amount of thyroid tissue. The autologous implantation of thyroid tissue is thus feasible and safe.
\end{abstract}

Key words: Transplantation, Autologous. Thyroid Gland. Thyroidectomy.

\section{Introdução}

Há pouco estudo na literatura consultada sobre o aproveitamento da tireóide, na qualidade de tecido transplantado.

Os implantes autólogos da tireóide foram realizados no músculo esternocleidomastóideo, raiz do mesentério e ovário direito da rata ${ }^{4}$. A arquitetura celular e folicular foi preservada em todos os locais. Apenas no mesentério o tecido foi mais bem preservado ou regenerado.

O lobo esquerdo da tireóide foi excisado com as 
paratireóides e transplantadas na região pré-peritoneal com insucesso e falência dos auto-implantes ${ }^{5}$.

Pela escassez de trabalhos sobre o aproveitamento da tireóide, iniciou-se uma linha de pesquisa em que a tireóide tornou-se em parte enxerto autólogo.

O presente trabalho se propõe ao estudo da produção dos hormônios $\mathrm{T}_{3}, \mathrm{~T}_{4}$ pela glândula tireóide nos transplantes autólogos na raiz do mesentério em ratos.

\section{Métodos}

Foram utilizados quarenta e dois ratos Wistar, com peso médio de $230 \mathrm{~g}$.

O grupo 1 formado por trinta ratos, nos quais implantaram-se dois fragmentos eqüidistantes $0,5 \mathrm{~cm}$ de tireóide na gordura do mesentério.

Antes dos transplantes foi colhido $1 \mathrm{ml}$ de sangue (primeira colheita) para dosagem de $\mathrm{T}_{3}, \mathrm{~T}_{4}, \mathrm{TSH}$ e IgG. Dez dias após dos transplantes autólogo, colheu-se o sangue (segunda colheita) dos animais para nova análise e realizada a tireoidectomia do lobo direito, encaminhado-o para a histologia. Os animais foram deixados trinta dias com os transplantes da tireóide, quando se fez a terceira colheita. A partir deste momento fez-se as colheitas de quinze/quinze dias até a sexta e última colheita.

No grupo 2 composto de dez ratos, com peso médio de $280 \mathrm{~g}$, fez-se os transplantes na raiz do mesentério. Após dez dias realizou-se a tireoidectomia do lobo direito, deixando-os sobreviver com os implantes autólogos durante cem dias.

O grupo 3 formado por dois ratos, onde foram repetidos os procedimentos do grupo anterior. No final de cem dias os espécimes foram preparados para fazer a microscopia eletrônica.

As operações foram realizadas sob anestesia com tiopental sódico, administrado por via intraperitoneal na dose de $30 \mathrm{mg} / \mathrm{kg}$ de peso corporal. Anti-sepsia foi feita com álcool a $70 \%$, utilizando-se campos esterilizados. O lobo esquerdo da tireóide foi cortada com bisturi em dois pedaços de $2,50 \mathrm{~mm} \mathrm{x}$ $1,3 \mathrm{~mm} \times 1,6 \mathrm{~mm}$ e implantou-se na raiz do mesentério com o monofilamento preto 6-0. Fez-se a laparotomia para a colheita do sangue na veia cava inferior. Feita a síntese da parede abdominal e região cervical por planos com pontos separados. Os implantes foram removidos, fixados em líquido de Bouin, desidratados em álcool, clareados em xilol e incluídos em parafina. As secções foram coradas pela Hematoxilina e Eosina. No estudo morfométrico dos transplantes autólogos foi utilizado o Sistema de Análise e Processamento de Imagens LEICA 500MC, calibrado para objetiva de X20, cuja área total analisada por animal foi de $585.936 \mu \mathrm{m}^{2}$.

As estruturas consideradas foram os folículos e o material colóide da tireóide. Para efeito de cálculos, os folículos tireóideos foram considerados estruturas esféricas. Calcularamse os parâmetros: volume folicular, densidade do volume folicular e densidade numérica. $\mathrm{O}$ índice de significância aceita foi 0,005 .

O volume de sangue colhido de $1 \mathrm{ml}$ foi colocado em frascos etiquetados com identificação do animal. O método usado para a dosagem hormonais foi a Quimioluminescência, ACS-180-CHIRON. Requer apenas $\mathrm{T}_{3}=25 \mu \mathrm{l} ; \mathrm{T}_{4}=12,5 \mu \mathrm{le}$ $\mathrm{TSH}=50 \mu \mathrm{l}$. Os valores de IgG foram obtidos pela técnica de imunodifusão radial.

\section{Resultados}

Distingue-se a glândula tireóide no tecido gorduroso marcado pelo segmento monofilamentar preto (Figuras1 e 2).

$\mathrm{O}$ aumento de peso dos animais no período de 85 dias teve variação média de 8 gramas. Não houve animais obesos ou emagrecidos.

Os homônios triiodotironina $\left(\mathrm{T}_{3}\right)$, tetraiodotironina $\left(\mathrm{T}_{4}\right)$, hormônio estimulante da tireóide (TSH) e imunogamaglobulina (IgG) estão representados na Tabela 1. Os animais estavam com a tireóide in situ no período préoperatório e dez dias de pós-operatório, por isso não houve modificações significantes nas oscilações dos valores hormonais.

TABELA 1 - Dosagem dos hormônios e IgG.

\begin{tabular}{|l|c|c|c|c|}
\hline & $\mathbf{T}_{\mathbf{3}} / \mathbf{n g} / \mathbf{d l}$ & $\mathbf{T}_{\mathbf{4}} / \mathbf{\mu g} / \mathbf{d l}$ & $\mathbf{T S H} / \boldsymbol{\mu U} / \mathbf{m l}$ & $\mathbf{I g G} \mathbf{~ m g} / \mathbf{d l}$ \\
\hline Colheita & $\mathrm{M} \mathrm{DP}$ & $\mathrm{M}$ DP & $\mathrm{M}$ DP & $\mathrm{M}$ DP \\
\hline Pré-cirurgia & $46,7 \pm 6,6$ & $1,9 \pm 0,4$ & $1,3 \pm 0,7$ & $1210 \pm 1291$ \\
\hline 10 dias & $48,2 \pm 7,6$ & $1,8 \pm 0,4$ & $2,0 \pm 1,1$ & $1186 \pm 1246$ \\
\hline 30 dias & $29,3 \pm 5,3$ & $1,8 \pm 0,5$ & $16,6 \pm 5,8$ & $1069 \pm 395$ \\
\hline 45 dias & $36,1 \pm 10,6$ & $1,6 \pm 0,4$ & $11,3 \pm 5,0$ & $956 \pm 392$ \\
\hline 60 dias & $40,3 \pm 8,5$ & $1,6 \pm 0,4$ & $11,5 \pm 2,9$ & $1095 \pm 773$ \\
\hline 75 dias & $46,8 \pm 5,6$ & $1,7 \pm 0,4$ & $13,6 \pm 5,2$ & $754 \pm 176$ \\
\hline
\end{tabular}

$\mathrm{M}=$ Média; $\mathrm{DP}=$ Desvio Padrão 


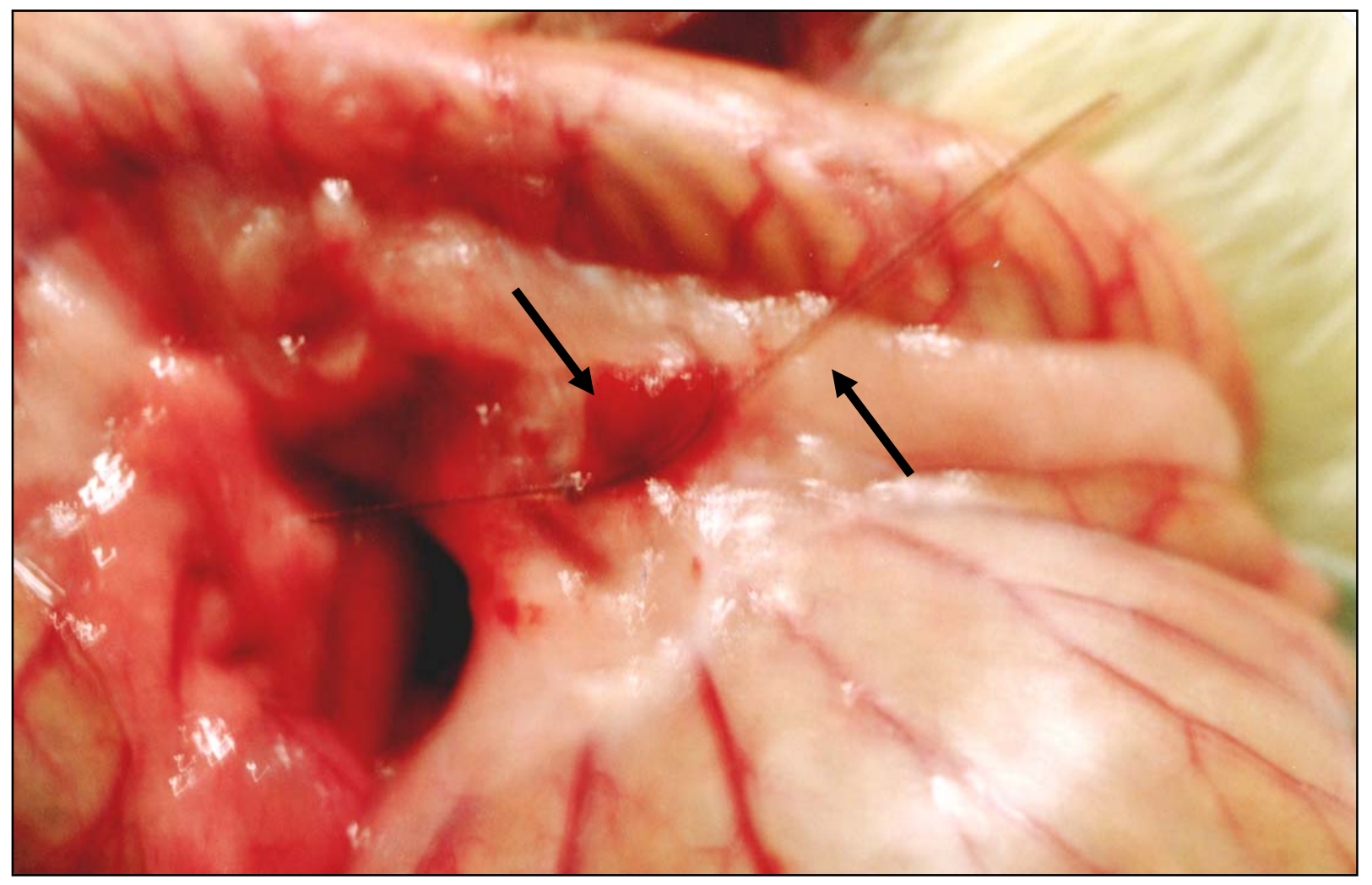

FIGURA 1 - Transplante autólogo de tireóide após 85 dias

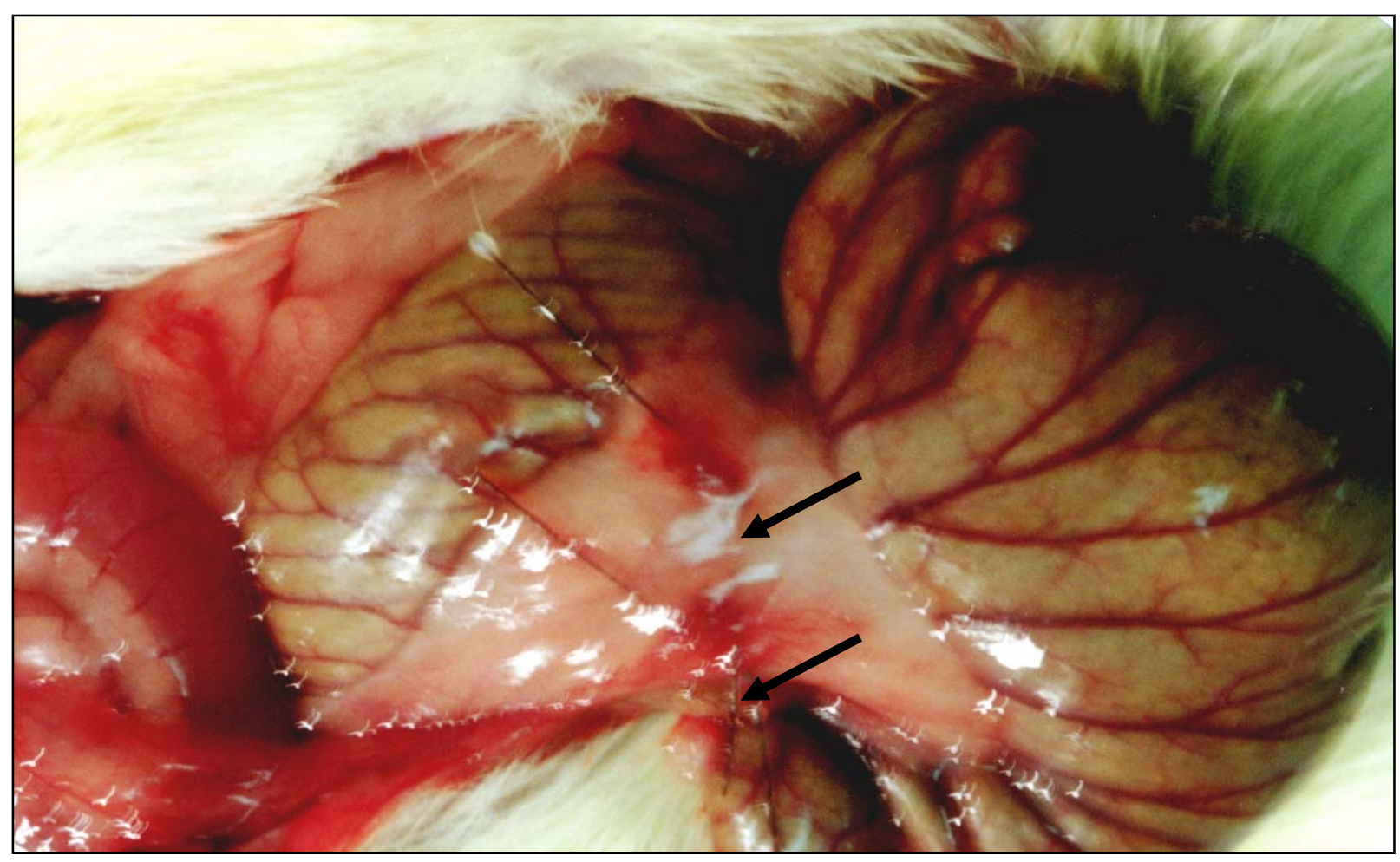

FIGURA 2 - Transplante autólogo de tireóide após 85 dias 
Os números obtidos do sangue colhido nos animais foram analisados pelo teste de Wilcoxon. A Figura 3 resume o comportamento do $\mathrm{T}_{3}$ mostrando que na primeira e segunda colheita não houve alteração significante. Até porque os animais ainda tinham a tireóide in situ. Na terceira colheita teve uma alteração significante deste hormônio, quando a curva evoluiu em direção aos valores iniciais.

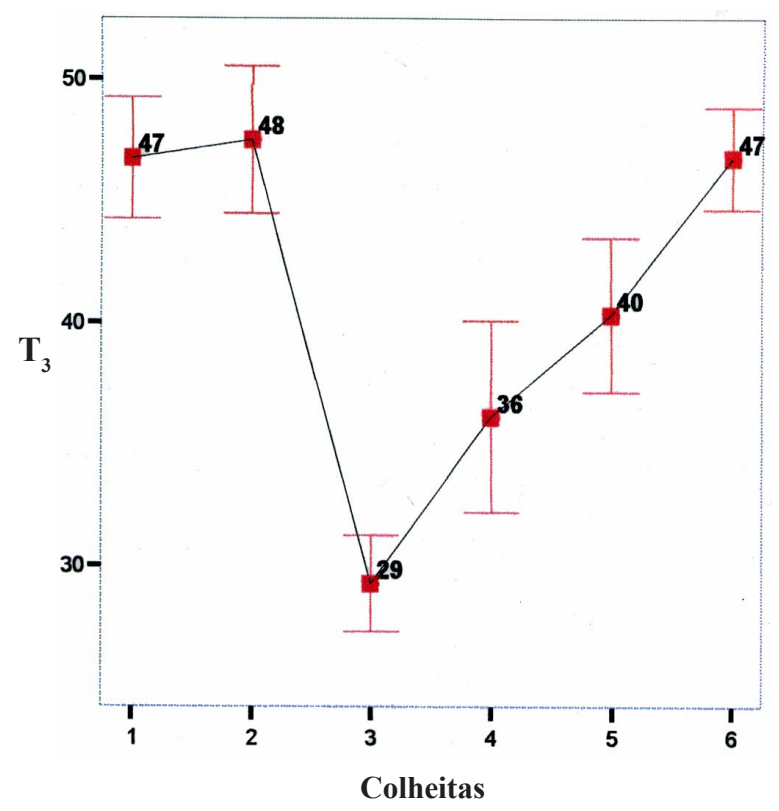

FIGURA 3 - Distribuição da curva de $T_{3}$ nas colheitas $\left(\mathrm{C}_{1,2,3,4,5,6}\right)$

A Figura 4 mostra as alterações discretas, pouco significante de $\mathrm{T}_{4}$ na primeira e segunda colheitas, nos animais ainda com a tireóide in situ. Manteve-se estável na terceira colheita, baixou na quarta colheita e daí começou a subir em direção aos valores iniciais.

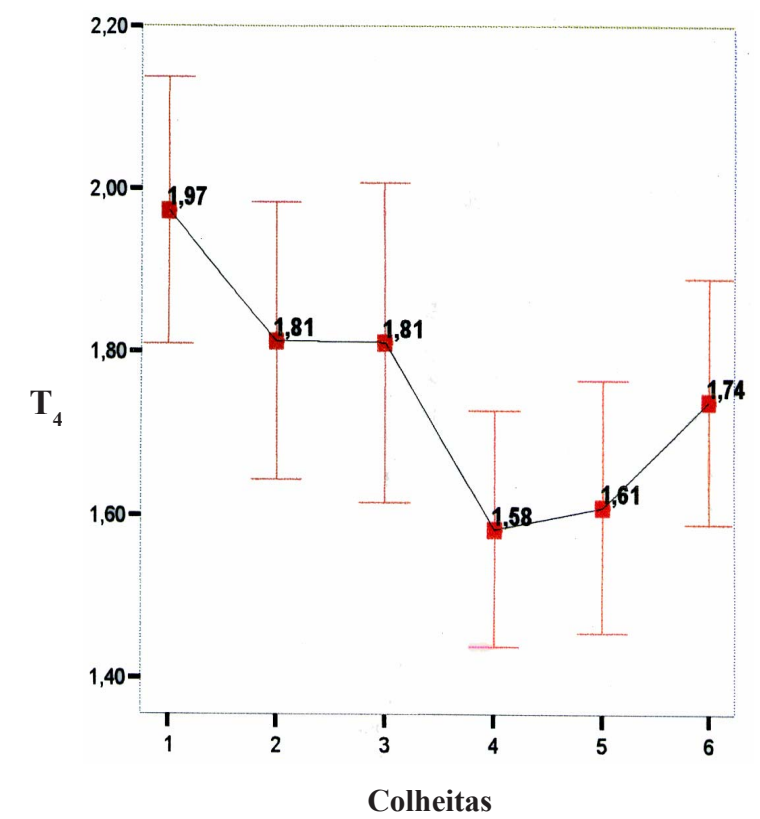

FIGURA 4 - Distribuição da curva de $\mathrm{T}_{4}$ nas colheitas $\left(\mathrm{C}_{1,2,3,4,5,6}\right)$
A Figura 5 mostra a distribuição dos valores do TSH, o que repete a normalidade na primeira e segunda colheitas. $\mathrm{Na}$ terceira houve um pico máximo. Caiu na quarta e manteve-se altos até a última colheita.

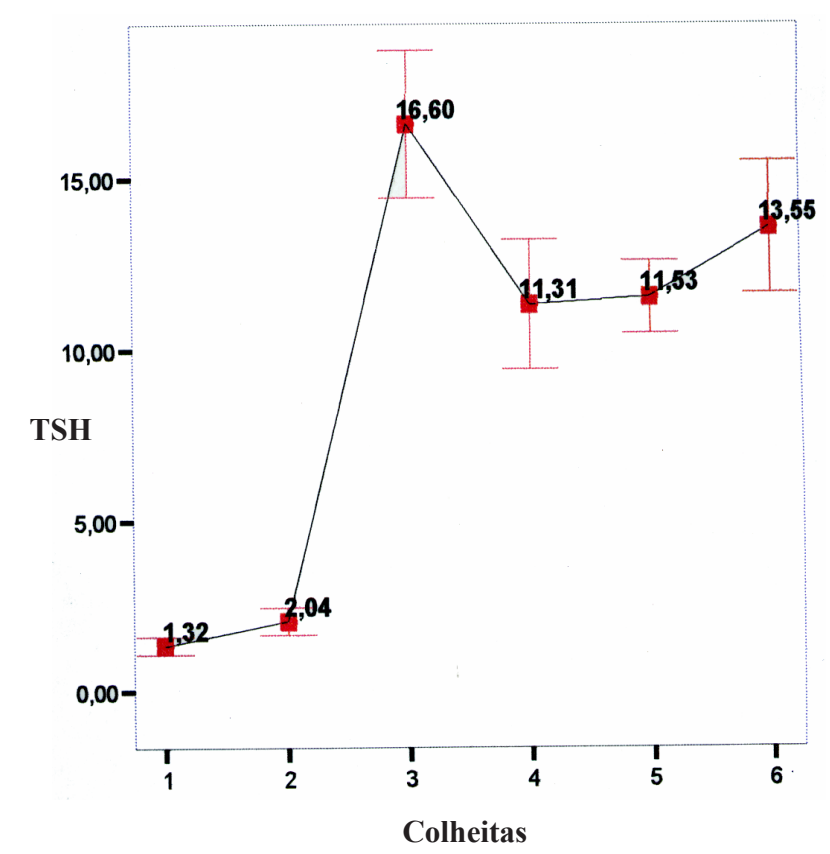

FIGURA 5 - Distribuição da curva de TSH nas colheitas $\left(\mathrm{C}_{1,2,3,4,5,6}\right)$

A Figura 6 mostra discreta modificação da curva linear da IgG. Considerando a primeira e última colheita do sangue dos animais.

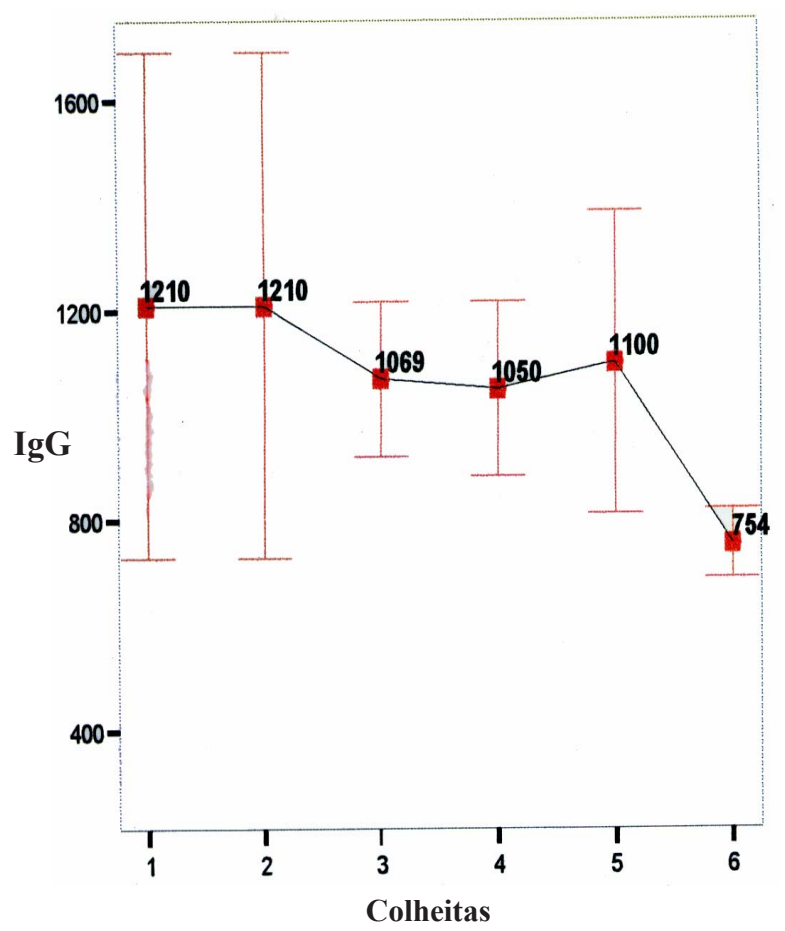

FIGURA 6 - Distribuição da curva de IgG nas colheitas $\left(\mathrm{C}_{1,2,3,4,5,6}\right)$ 
O corpo celular apresentou atividade de síntese vista no retículo endoplasmático rugoso, nas células epiteliais de revestimento dos folículos, o qual apresentava vesículas dilatadas, formando cisternas preenchidas por material de secreção finamente grumoso e uniforme. Os aparelhos de Golgi, as mitocôndrias foram vistos bem desenvolvidos. Alguns folículos atrofiados foram encontrados ao lado desta área de atividade, com epitélio de revestimento fortemente achatado e colóide espesso com alguns grumos no seu interior.

Foram achados os aspectos ultra-estruturais da glândula tireóide transplantada para a gordura do mesentério após cem dias. Na parte superior da figura aparece o colóide espesso e homogêneo, delimitado abaixo por uma célula epitelial comprimida e achatada, revelando uma área inativa da tireóide.

$\mathrm{Na}$ Figura 7A observou-se colóide espesso e homogenia; a Figura 7B apresenta as dilatações dos retículos e cisterna secretoras; na Figura 7C vê-se mitocôndrias e retículo endoplasmático rugoso e na Figura 7D se observam vários núcleos epiteliais e o retículo endoplasmático dilatado.

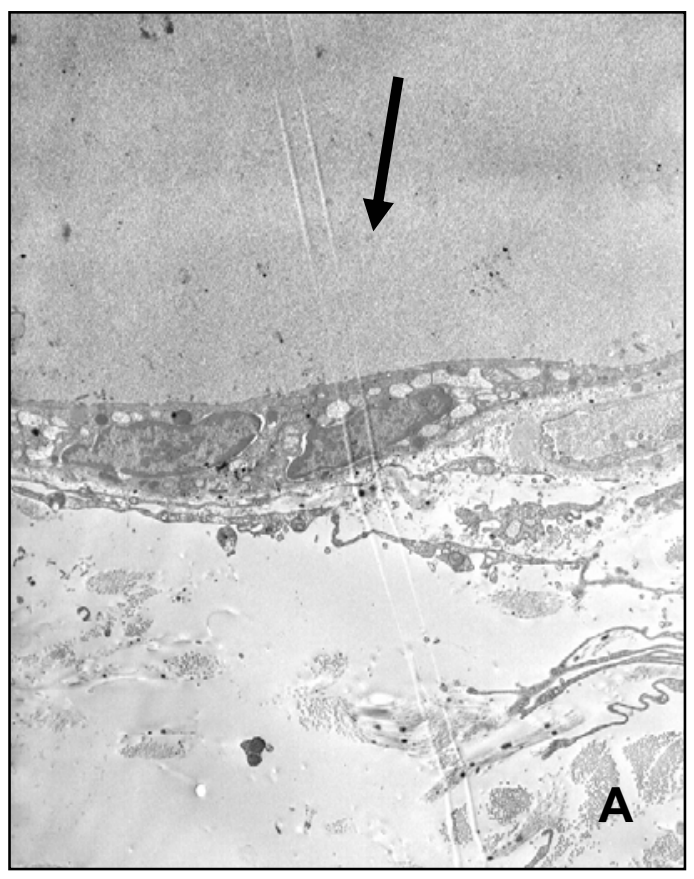

FIGURA 7A - X3.000. Colóide espesso

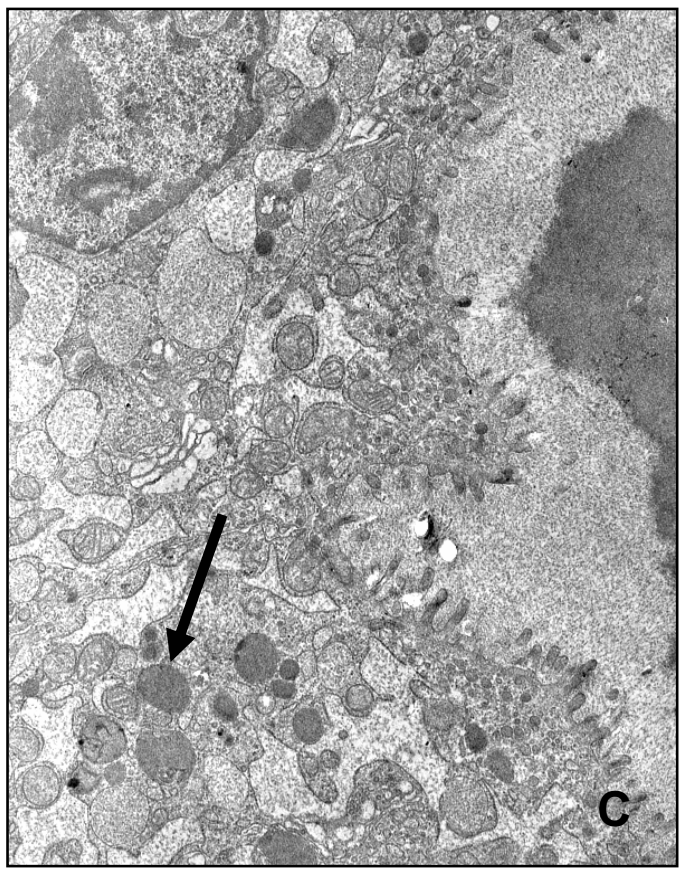

FIGURA 7C - X7.000. Mitocôndrias

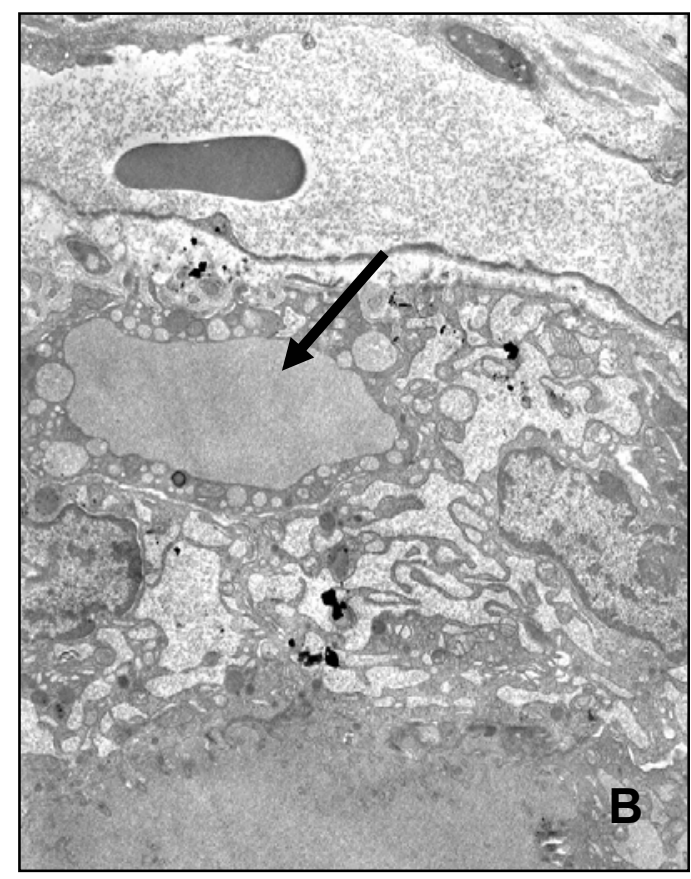

FIGURA 7B - X4.400. Cisterna

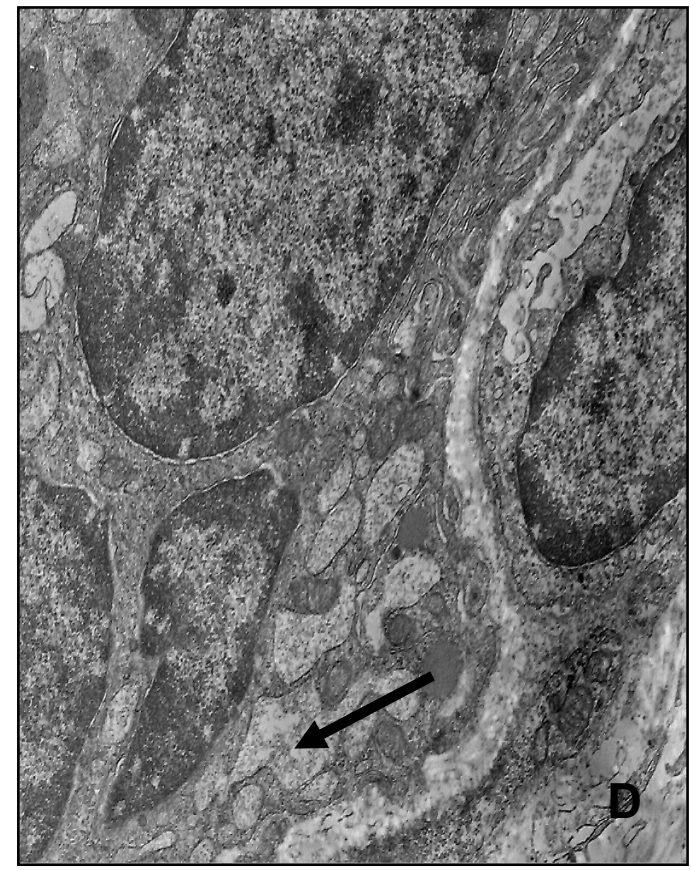

FIGURA 7D - X7.000. Retículo endoplasmático 
A glândula tireóide transplantada na raiz do mesentério, em geral, se manteve inalterada. Apresentou variável edema e discreta infiltração leucocitária mononuclear. Os folículos com diâmetros variáveis estão forrados com epitélio achatado. O epitélio secretor variou de cúbico a achatado. O colóide apareceu homogêneo, fino, eosinofílico e contendo algumas células descamadas no seu interior. A glândula paratireóide apareceu aderida à cápsula tireóide sem alterações.

A glândula tireóide transplantada se manteve comparável com a glândula tireóide in situ (Figura 8, A, B, C e D).

\section{Aspectos histológicos dos transplantes autólogos da tireóide}

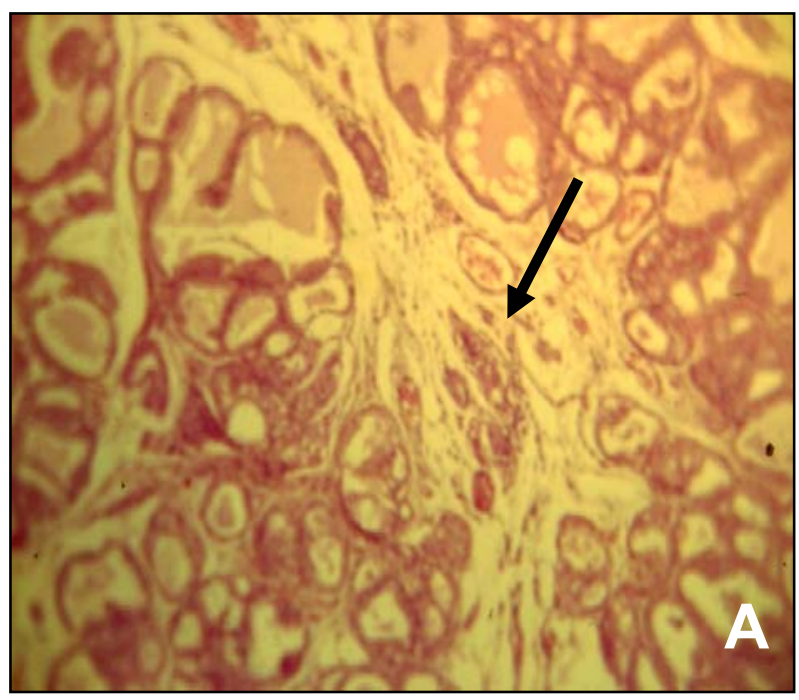

FIGURA 8A - X100. Edema intersticial

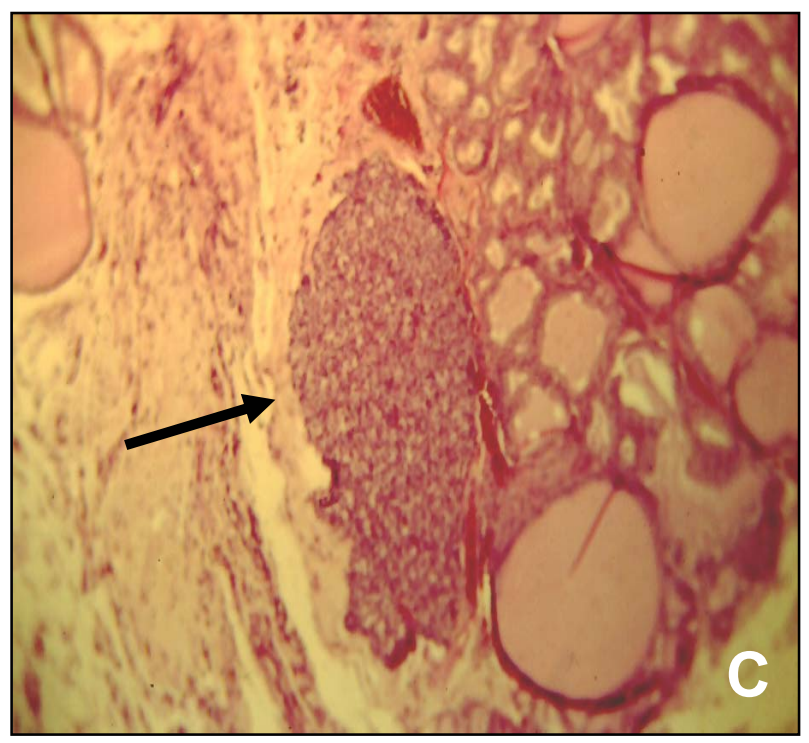

FIGURA 8C - X100. Folículos tireóideos e Paratireódeo

O volume médio dos folículos da tireóide transplantada foi reduzido. A densidade de volume teve pequena redução observados no período de 85 dias do transplante autólogo da tireóide na raiz do mesentério. A densidade numérica aumentou com significado estatístico $(\mathrm{p}<0,001)$.

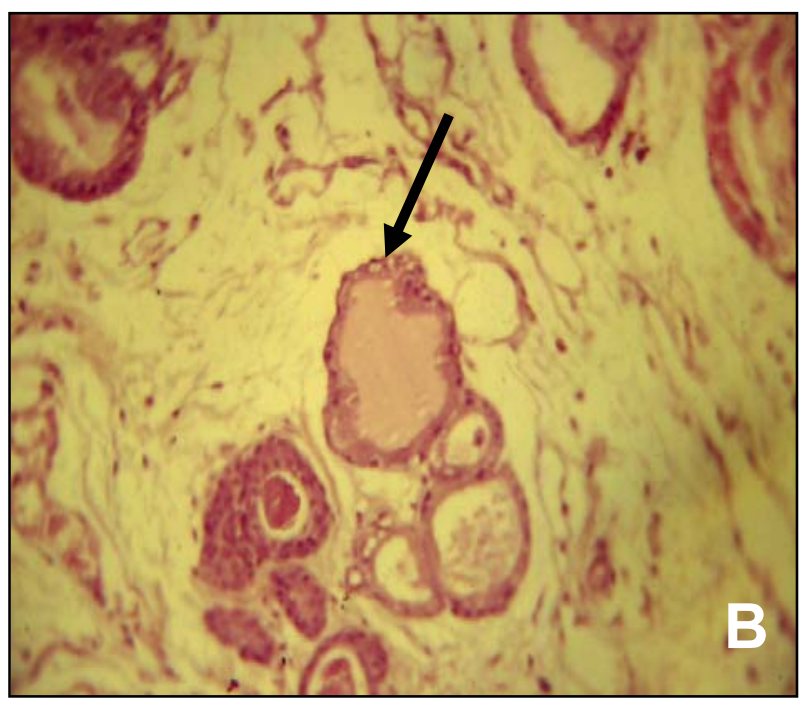

FIGURA 8B - X160. Folículos hipotróficos

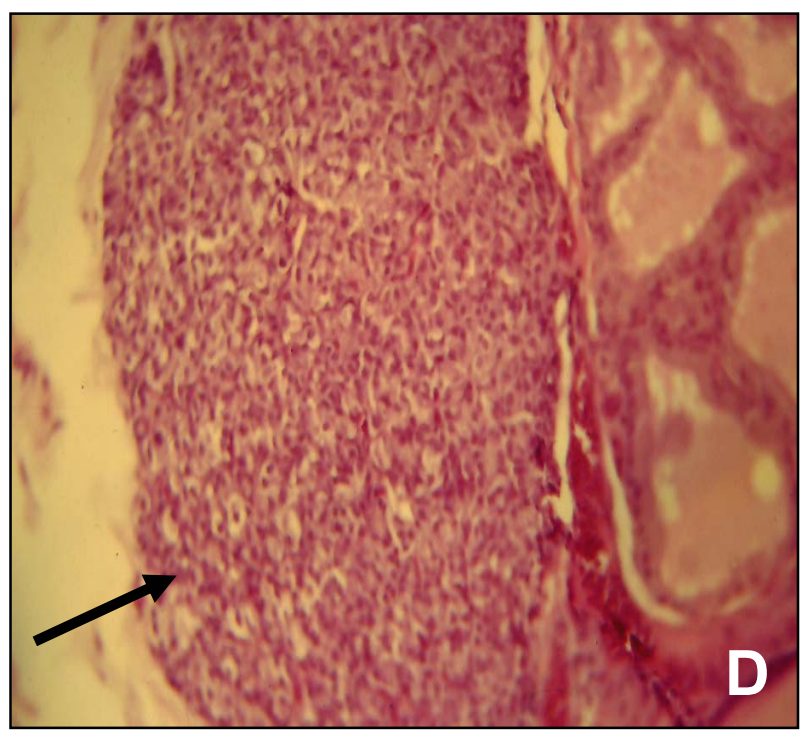

FIGURA 8D - X160. Paratireóide

\section{Discussão}

As glândulas paratireóides quando removidas no curso da cirurgia da tireóide, possuem uma alternativa adequada para o implante autólogo ${ }^{1}$. 
A glândula tireóide, no desenvolvimento embrionário normal, localiza-se na região anterior do pescoço. Mas quando a descida é incompleta a tireóide pode ser localizada na base da língua ${ }^{2}$.

As células da tireóide do rato atímico, em dispersão, foram injetadas na região dorsal e inguinal do animal. Os níveis de $\mathrm{T}_{3}$ e $\mathrm{T}_{4}$ reverteram-se aos valores normais até a sexta semana. O TSH aproximou-se dos níveis normais em seis semanas ${ }^{3}$.

Buscou-se, então, um modelo mais prático para facilitar o transplante autólogo da glândula tireóide, com menor custo, viabilidade técnica, de maneira a preservar a vitalidade do tecido. Foram escolhidos o músculo esternocleidomastóideo, o ovário e a raiz do mesentério. Estes implantes autólogos da tireóide foram viáveis e como melhor local, a raiz do mesentério ${ }^{4}$.

O estudo histológico e a ultra-estrutura revelaram que a glândula tireóide transplantada sofre o processo inflamatório, mas logo há uma estabilização seguido da regeneração e diferenciação em folículos. Este fato mostra a extraordinária capacidade da tireóide e das paratireóides, nutridas pela difusão do líquido peritoneal, manterem a estrutura da arquitetura celular e folicular, sem sofrerem a necrose ou absorção dos implantes. É possível que o tecido gorduroso do mesentério seja o responsável pelo melhor meio nutricional. Observou-se uma maior rede vascular nas proximidades dos auto-enxertos. Isto pode significar um fator fundamental para a sobrevivência dos transplantes livres no abdome. Este local é notificado como região liberadora de fatores angiogênicos como uma reação natural. A capacidade regenerativa da glândula tireóide e sua resistência à privação de oxigênio parecem muito grande, a ponto de ficar dependendo do surgimento de um suprimento sangüíneo pelos vasos neoformados.

Nos espécimes estudados não foram observadas atipias celulares. Na morfometria, o compartimento analisado foi $585936 \mu \mathrm{m}^{2}$ por animal. Houve grande redução do volume folicular e a diminuição da densidade de volume que pode ser interpretado pelo processo de hipotrofia folicular. O aumento significante da densidade numérica folicular no compartimento estudado, pode ser indicativo da discreta hipotrofia do tecido da glândula tireóide.

O estudo histológico mostrou que junto da tireóide viase a paratireóide que também é facilmente implantável em iguais condições e que contribuiu para a sobrevivência dos animais.

O perfil hormonal revela a capacidade dos fragmentos de manter a arquitetura celular e folicular, respondendo com a produção dos hormônios $\mathrm{T}_{3}$ e $\mathrm{T}_{4}$.

Os animais do grupo 1, na primeira e segunda colheita do sangue, estavam com o lobo direito da tireóide in situ. Nestes dois momentos, não houve modificação significante dos valores de $\mathrm{T}_{3}, \mathrm{~T}_{4}$ e TSH.

$\mathrm{O} \mathrm{T}_{3}$, na terceira, quarta e quinta colheitas tiveram diferenças estatisticamente significantes $p<0,005$. Na sexta colheita com $\mathrm{p}=0799$ já não havia significação estatística com os valores normalizados.

$\mathrm{O}$ significado estatístico em $\mathrm{T}_{4}$ não teve expressão, considerando $\mathrm{p}<0,005$ e os valores absolutos penderam para a normalidade.

O TSH na terceira, quarta, quinta e sexta colheitas teve $\mathrm{p}<0,005$, por isso permaneceu com diferença significante.

$O$ teste de Wilcoxon foi aplicado na imunogamaglobulina, porém os resultados não tiveram significado estatístico.

\section{Conclusão}

O transplante autólogo da glândula tireóide é factível, com preferência na raiz do mesentério. As arquiteturas morfológica e ultra-estrutural são preservadas. A função hormonal da glândula tireóide auto-implantada responde produzindo $\mathrm{T}_{3}, \mathrm{~T}_{4}$.

Com base nesses resultados, julgamos viável, por exemplo, em uma situação de trauma da região infrahióidea, arrancamento ou outra situação desagregadora da tireóide in situ, poder-se tentar o transplante autólogo da glândula no ser humano.

\section{Referências}

1. Rothemund M, Wagner PK, Schark C. Subtotal parathyroidectomy versus paarthyroidectomy and transplantation in secondary hiperparathyroidism. World J Surg. 1991; 15:745-50.

2. Lahey FH. Lingual goither. Surg Gynecol. 1927;36:315-97.

3. Mulcahy RT, Mott RK, Clifton KH. Transplantation of monodispersed rat cells humoral: effects on follicular unit development and morphology. Proc Soc Exp Biol Med. 1980;163:100-10.

4. Mota JCN, Lázaro da Silva A, Andrade ZA, Barbosa Jr AA. Aspectos morfológicos dos autotransplantes de tireóide da rata. Rev Col Bras Cir. 1999;26(3):135-9.

5. Halsted WS. Auto and isotransplantation, in dog, of the parathyroid gland. J Exp Med. 1909;11:175-99.
Correspondência:

José Carlos Nunes Mota

Rua Vicente Batalha, 268/503

41760-030 Salvador - BA

jcnmota@bol.com.br
Conflito de interesse: nenhum

Fonte de financiamento: nenhuma

Recebimento: 22/07/2004

Revisão: 02/09/2004

Aprovação: 06/10/2004

\section{Como citar este artigo:}

Mota JCN, Silva AL, Barbosa Jr AA, Nascimento M. Aspectos funcionais e imunológico do transplante autólogo da tireóide em ratos. Acta Cir Bras [serial online] 2004 Nov-Dez;19(6). Disponível em URL: http://www.scielo.br/acb [também em CD-ROM].

*Figuras coloridas disponíveis em www.scielo.br/acb 